\title{
Marco Nuti, Pour une poétique thanatologique: la mort dansante chez Balzac, Poe et Baudelaire, in «Revue romane», XLII, $\mathrm{n}^{\circ} 2$
}

\section{Marco Stupazzoni}

\section{(2) OpenEdition}

\section{Journals}

\section{Edizione digitale}

URL: http://journals.openedition.org/studifrancesi/7977

DOI: $10.4000 /$ studifrancesi.7977

ISSN: 2421-5856

\section{Editore}

Rosenberg \& Sellier

\section{Edizione cartacea}

Data di pubblicazione: 1 juillet 2009

Paginazione: 415

ISSN: 0039-2944

\section{Notizia bibliografica digitale}

Marco Stupazzoni, «Marco Nuti, Pour une poétique thanatologique: la mort dansante chez Balzac, Poe et Baudelaire, in «Revue romane», XLII, n² 2», Studi Francesi [Online], 158 (LIII | II) | 2009, online dal 30 novembre 2015, consultato il 13 janvier 2021. URL: http://journals.openedition.org/studifrancesi/7977 ; DOI: https://doi.org/10.4000/studifrancesi.7977

Questo documento è stato generato automaticamente il 13 janvier 2021.

\section{cc) (†) $\odot$}

Studi Francesi è distribuita con Licenza Creative Commons Attribuzione - Non commerciale - Non opere derivate 4.0 Internazionale. 


\title{
Marco Nuti, Pour une poétique thanatologique: la mort dansante chez Balzac, Poe et Baudelaire, in «Revue romane», XLII, $\mathrm{n}^{\circ} 2$
}

\author{
Marco Stupazzoni
}

\section{NOTIZIA}

MARCO NUTI, Pour une poétique thanatologique: la mort dansante chez Balzac, Poe et Baudelaire, in «Revue romane», XLII, n² 2, 2007, pp. 256-270.

1 Il tema del ballo, così diffuso nella produzione poetica e romanzesca della letteratura romantica, si intreccia assai frequentemente con quello della "danse macabre" in cui il tema della morte è reso ancor più efficace ed enigmatico attraverso l'immagine (o l'apparenza) della seducente bellezza femminile sotto il cui fascino l'uomo soccombe. Nelle opere prese in esame dall'autore (Sarrasine di Balzac, Le Masque de la mort rouge di Poe e «Danse macabre» di Baudelaire), «l'homme, avili par les plaisirs, se trouve [...] incapable de distinguer ce qui lui devrait sauter aux yeux: la mort» (p. 263). Questo «enlisement dans la matière» (p. 266) acquista, nel racconto di Balzac, un significato particolare esemplificato nella palese impossibilità da parte dell'artista di comprendere la vera origine della bellezza di Zambinella. Svelare, osserva l'autore, «le masque sous lequel se cache la beauté provoque la mort de l'artiste» (p. 269). «L'attachement à la matière, au corps féminin aux dépens de l'esprit, apporte donc la mort de l'art puisque l'unité devient inaccessible par faute de spiritualité» (pp. 268-269). 